強制放電分散型電解放電加工の加工特性(第 2 報)

一加工電流の観察一

古谷克司* 新谷啓行* 村瀬靖男* 荒川修一*

\title{
Performance of Electrochemical Discharge Machining by Forced Discharge Dispersion (2nd Report) Monitoring of Machining Current
}

Katsushi FURUTANI, Hiroyuki SHINTANI, Yasuo MURASE and Shuichi ARAKAWA

\begin{abstract}
This paper deals with the monitoring of the current during electrochemical discharge machining (ECDM) with multiple electrodes. A gravity-feed-type unit with six electrodes for ECDM was fabricated. The polarity of the electrodes was set to be negative. While some holes were machined by ECDM on glass, the discharge current was forced to disperse by switching the electrodes to decrease the number of cracks (divided power). The current in the divided power was observed during the machining process and compared with those in the cases of multiple electrodes connected electrically in parallel (equipotential) and of a single electrode. Bubbles were generated by current pulses with a duration of several milliseconds when the voltage was applied. However, they disappeared during pulse intervals. A current pulse with a duration of two to five milliseconds preceded a series of sharp pulses below $200 \mu \mathrm{s}$ in the single-electrode and divided-power methods. Long and low-peak-current pulses frequently occurred, and the current pulses were concentrated at the electrodes at the two ends with equipotential power.
\end{abstract}

Key words : multiple electrode, bubble, divided power, equi-potential power, discharge, electrolysis

\section{1. 緒 論}

ガラス，圧電セラミックスなどの絶縁性ぜい性 材料に対して, 前後処理が少なく, 柔軟性が高く, 小規模で安価な装置で行える微細加工法が求めら れている. 電解放電加工はその要求を満たす加工 法の一つである 1)2.

電解放電加工では，水酸化ナトリウム水溶液な どの電解液を加工液とする．陰極である工具電極 先端を絶縁性の工作物に軽く押し付けた状態で印 加電圧を上昇させると, 工具電極表面全体が気泡
に覆われ，工具電極と電解液間の電位差により放 電が発生する 1 . この放電の熱もしくは泡の境界 を電流が流れるときのジュール熱 3)によって，工 作物と電解液との化学反応が促進されることによ り除去される.ナトリウムイオン $\left(\mathrm{Na}^{+}\right)$を含む電解 液を用いてガラスの電解放電加工時には式(1)の 化学反応により, $\mathrm{Na}^{+}$が O-Si-O の結合を切り, 水 溶性のケイ酸ナトリウムが生成される ${ }^{4}$.

$$
\mathrm{SiO}_{2}+2 \mathrm{NaOH} \rightarrow \mathrm{Na}_{2} \mathrm{SiO}_{3}+\mathrm{H}_{2} \mathrm{O}
$$
そしてケイ酸ナトリウムが電解液中に溶解するこ とで加工が進行する. 絶縁物は熱伝導率が低いた め, 熱膨張により加工部にクラックが発生するこ 


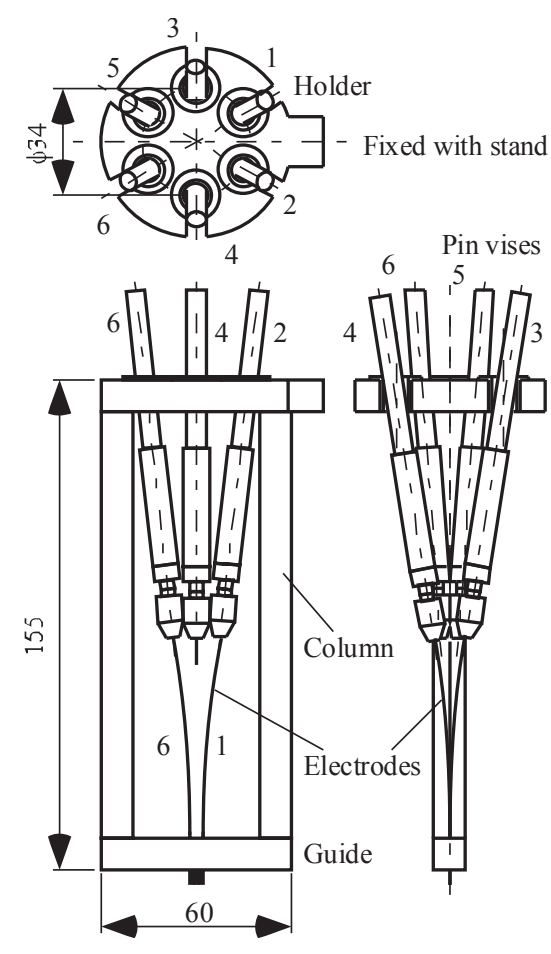

Fig. 1 Machining unit ${ }^{9)}$

\section{とが多い。}

著者らは旋盤型の電解放電加工機を試作し，放 電点を移動させることで泠却時間を設け，クラッ クが少ない加工を実現した 5)。また，ガラスの加 工中の主分力を測定し，熱による昇華ではなく， 生成されたケイ酸ナトリウムが加工液に溶解する ことが除去の主要因であることを明らかにした ${ }^{6)}$.

一方， 6 本の電極を独立して送ることで 3 次元 形状を加工するドットマトリクス方式放電加工法 では，各電極に独立に給電することで放電を強制 的に分散させ，クラックが少ない加工を実現した 7)8)。これより，強制的な放電分散は，電解放電加 工においてもクラックの低減に効果があることが 期待できる。この考えに基づき，前報ではガラス 板に対する電解放電加工において，6 本の電極へ の給電を切り替えることで強制的に放電を分散し た場合(分散給電)と，電気的に並列に接続した場 合(並列給電)および単電極の場合の加工特性につ いて比較した 9)。その結果，分散給電は並列給電 よりも形状精度が高く, クラックが発生しにくい ことが明らかになった。また，発生する泡が形状 に影響を与えることも明らかになった．除去加工 機構や泡の発生には加工電流が大きく影響を与え

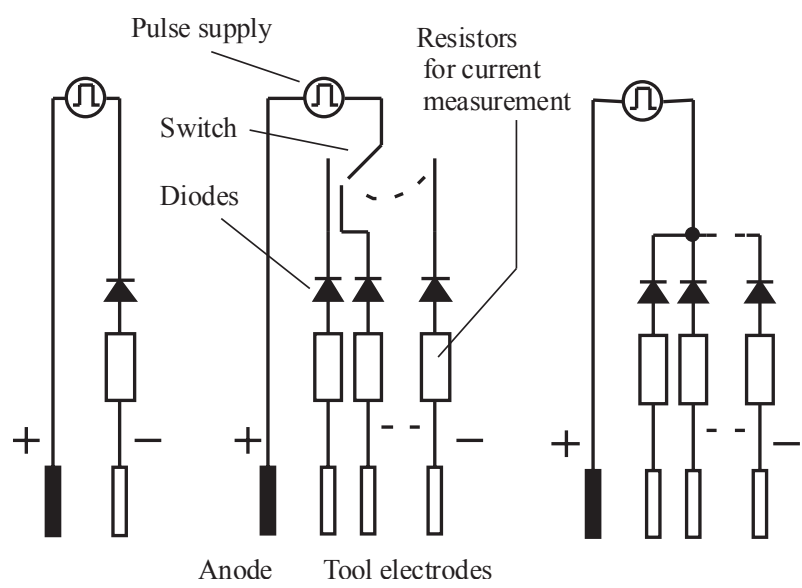

(a) Single

(b) Divided power

(c) Equi-potential electrode

power

Fig. 2 Discharge circuit $^{9)}$

ているはずであるが，給電方法による違いは明ら かになっていない. 電解放電加工においても，加 工電流の観察は加工現象の解析に有効である 10).

そこで本論文では，電解放電加工で複数の電極 を用いて放電を強制的に分散させた場合の加工電 流について述べる.

\section{2. 実験装置}

実験装置の構造を Fig. 1 に示す 9)。ピンバイス で保持した 6 本のタングステン電極を上側ホルダ では放射状に配置し，下側ガイドでは $0.8[\mathrm{~mm}]$ ピ ッチで一列に並べた。 ガイドではこれらをフッ素 樹脂チューブ(外径 $0.62[\mathrm{~mm}]$, 内径 $0.32[\mathrm{~mm}]$ ) で 絶縁し，電極が加工液に露出する長さを $4[\mathrm{~mm}]$ とした。電極は，ピンバイスの質量により被加工 物であるガラス板に押し付けられる。図中右から 1 から 6 の順で番号を付けた。

複数の電極に順次給電するため，パルス電源と なる。 パルス電源では，休止時間に被加工物が加 工液により冷却されるため，熱影響層を低減する のに効果があると言われている ${ }^{9)}$. 放電回路は Fig. 2 (a)の単電極，同図(b)の分散給電，同図(c)の並列 給電の 3 通りとした 9). 分散給電では, 電極への 給電を印加パルスと同期させて 1 パルスごとに切 り替えた。 N チャネル MOSFET(オン抵抗 $1[\Omega]$ ) をフォトカップラを介して TTL IC で構成したリ ングカウンタで駆動して回路を切り替えた。その ため，パルスは常に電極 1 から 6 の順で印加され 
Table 1 Machining conditions ${ }^{9)}$

$\begin{array}{ll}\text { Gap voltage } & 70[\mathrm{~V}] \\ \text { Pulse duration and interval } & 80[\mathrm{~ms}], 20[\mathrm{~ms}] \\ \text { Tool electrode } & \phi 0.3[\mathrm{~mm}] \text { tungsten }(-) \\ \text { Anode } & \text { Graphite } \\ \text { Resistor for current } & 1[\Omega] \\ \text { measurement } & 10[\mathrm{wt} \%] \mathrm{NaCl} \\ \text { Electrolyte } & 19[\mathrm{~g}] \\ \text { Mass of pin vise } & \mathrm{t} 1.3[\mathrm{~mm}] \text { Soda lime } \\ \text { Workpiece } & \text { glass } \\ & 0.5-40[\mathrm{~min}] \\ \text { Machining time } & \end{array}$

る．電極間の放電により電流が逆流することを防 ぐために各電極にはファーストリカバリーダイオ ード(耐圧 200[V]，接合容量 40[pF]@50[V]，逆回 復時間 $100[\mathrm{~ns}])$ を，電流を測定するために $1[\Omega]$ の抵抗を直列に接続した. これらの電圧降下は, 電源電圧に比べて無視できると考えられる.

加工条件を Table 1 に示す 9). 工具電極は $0.3[\mathrm{~mm}]$ のタングステン棒，被加工物はソーダ石 灰ガラスとした．加工液には塩化ナトリウム水溶 液を用い，加工時間の合計が $60[\mathrm{~min}]$ を超えない 範囲で交換した。

電圧および電流波形の記録には，チャネル間が 絶縁されている 12 ビット・ディジタルオシロス コープ(最高速度 $10[\mathrm{MS} / \mathrm{s}]$, アナログ帯域 $3[\mathrm{MHz}]$, 記録速度 $2[\mathrm{MS} / \mathrm{s}])$ を用いた。

\section{3. 加工実験}

\section{1 電流波形}

加工開始後 $40[\mathrm{~min}]$ 経過後の電流波形を比較す

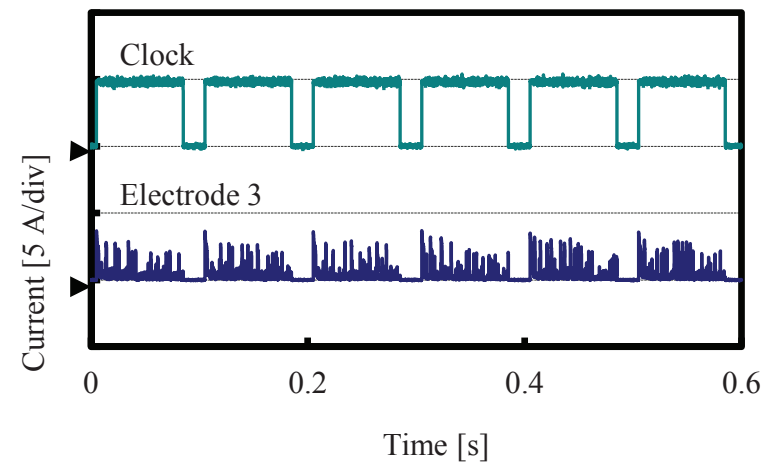

(a) Long period
る. 単電極給電の場合の電流波形を Fig. 3 に示す. 縦軸の三角印はそれぞれのゼロレベルを示す，同 図(a)で，クロック信号がハイレベルの時に電圧が 印加されている. 電圧印加直後の拡大図を同図(b) に示す，両図における時間軸は一致している。 0.305[s]で電圧が印加されると, ほぼ同時に数

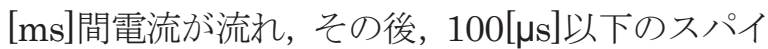
ク状の電流が断続的に流れた. また, 電圧印加直 後以外でも数 $[\mathrm{ms}]$ のパルス幅を持つ電流が流れ ることがあった。これらの現象は，電圧を印加す るごとに繰り返された. 別途行ったハイスピード カメラによる観察結果では, 最初の電流で泡が発 生, 成長し, その後放電が発生した。 電圧印加休 止時には泡が消滅した。したがって, 最初の数 $[\mathrm{ms}]$ のパルス幅を持つ電流で泡が発生し, 続く電 流で放電していると言える. 放電の前後にも $0.3[\mathrm{~A}]$ 程度の電流が流れていた.

分散給電の場合の電流波形を Fig. 4 に示寸. 電 極 1 から電極 6 の順で，スイッチング素子である MOSFET ヘゲート信号を与えた. それに応じて 電圧が印加される，同図(a)では，ゲート信号は電 極 1 の夕示している. 電圧を印加したチャネルで は Fig. 3 と同様の電流が観察された. 電極 1 の電 流波形も電極 2 から 6 までと同様の電流波形であ ったため, それぞれの電極は隣の電極で発生した 泡の影響を受けていないと考えられる，分散給電 では巡回するように給電するため，500[ms]間は 放電が起きず冷却が促進されると考えられる。拡 大した同図(b)からも Fig. 3 と同様の傾向である と言える.

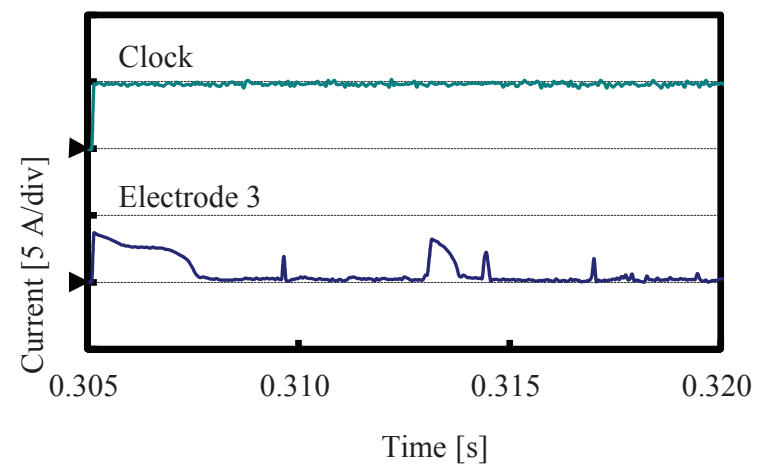

(b) Expanded view

Fig. 3 Example of machining current for single electrode 


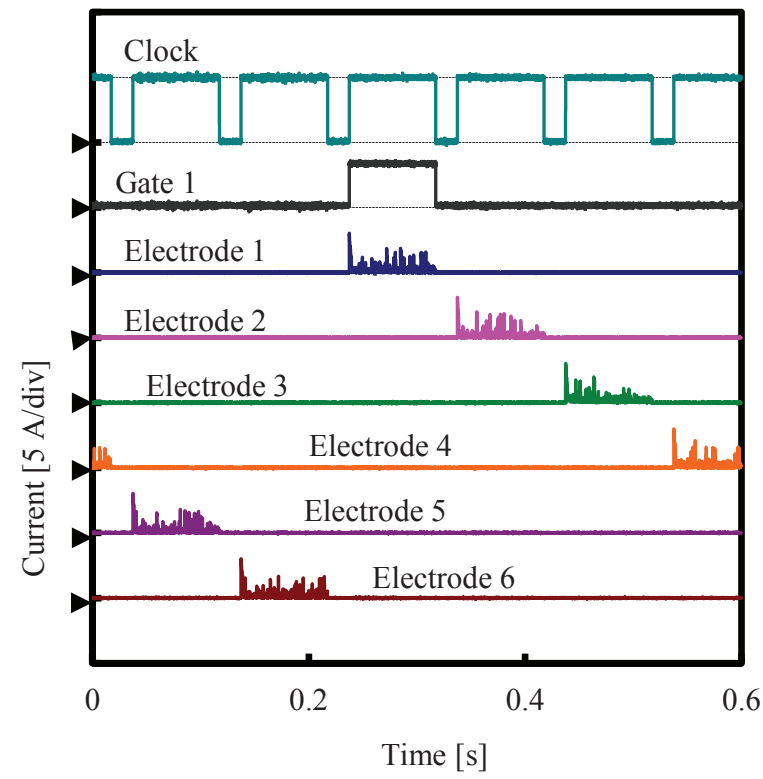

(a) Long period

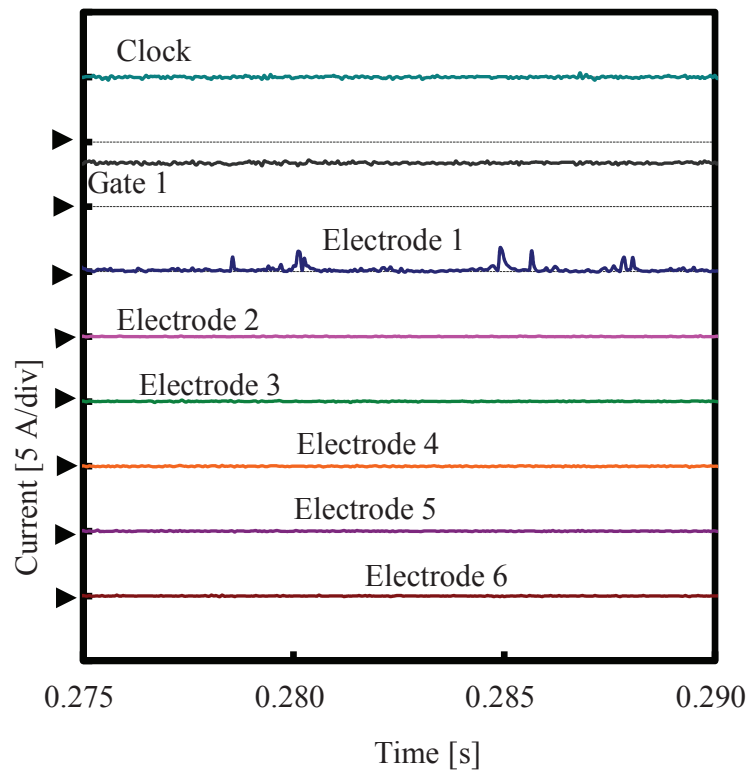

(b) Expanded view

Fig. 4 Example of machining current by divided power

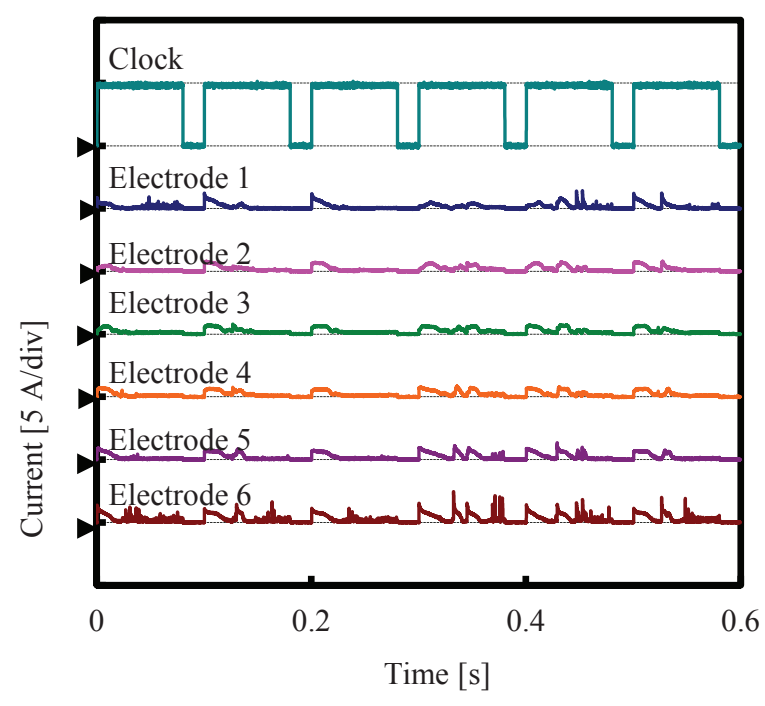

(a) Long period

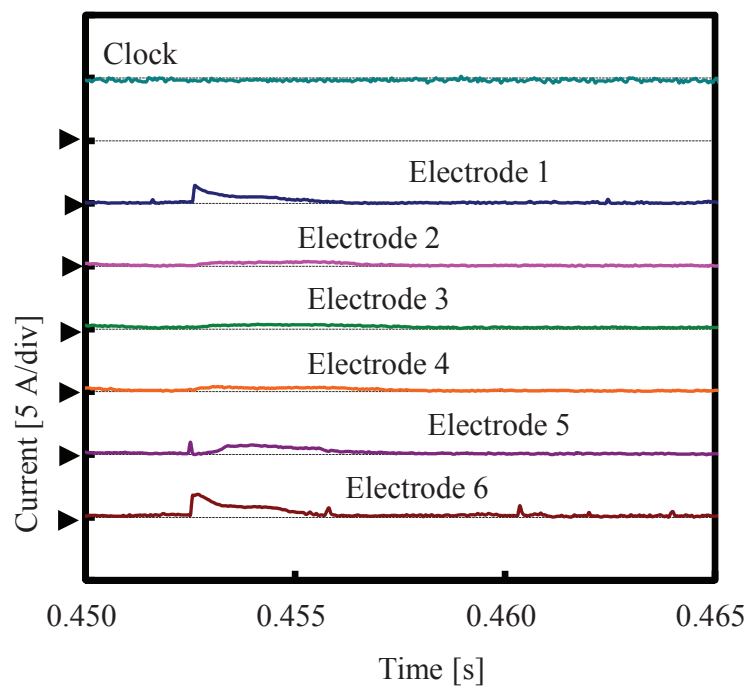

(b) Expanded view

Fig. 5 Example of machining current by equi-potential power

並列給電の場合の電流波形を Fig. 5 に示す．同 図(a)に示寸ように，パルス幅が長く，ピーク值が 小さい電流パルスが多く観察された。放電が発生 するためにはすべての電極が絶縁状態を形成する 必要があるためであると考えられる，絶縁を形成 するための電流は, 複数の電極で同時に流れた.

これらのパルスと, その後発生した短いパルス状 の加工電流とともに同図(b)に示寸. 放電と見られ
る電流の数は少なく, ピーク電流も小さかった. また，同時にはいずれか 1 本の電極でしか放電が 発生しなかった。

いずれの給電方式でも，短いパルスが約 20 [ $\mu \mathrm{s}$ ] であったので, サンプリング速度は $2[\mathrm{MS} / \mathrm{s}]$ で適 切である。

\section{2 各電極における電流パルス数}

ディジタルオシロスコープで取得した電流波形 


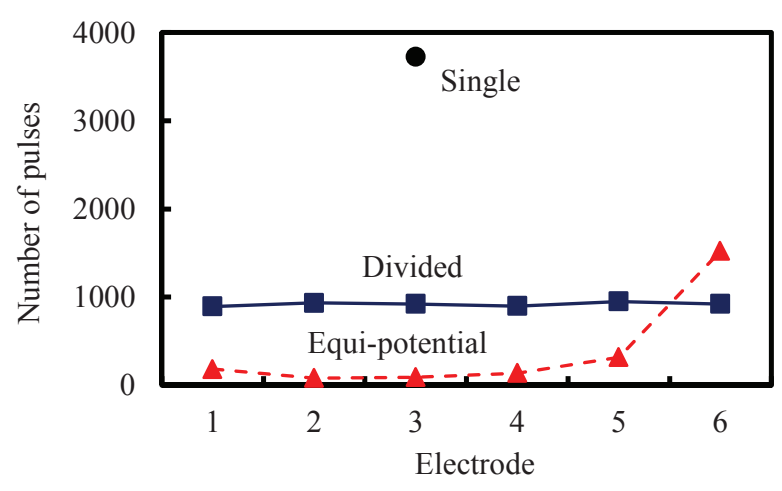

Fig. 6 Pulse distribution 20 min later

を処理するためのプログラムを $\mathrm{C}$ 言語により記述 した. Figs. 3 から 5 で示した結果では, 定常的に 流れる電流は約 0.3[A] で，他チャネルに電圧を印 加したときに発生するノイズは $0.2[\mathrm{~A}]$ 相当以下で あった．立ち上がりのしきい值を $0.5[\mathrm{~A}]$ ，立下り のしきい值を 0.3[A] とするヒステリシスを持たせ て，重畳されたノイズの影響を除去した。本プロ グラムでは，電流值とパルス幅の階級ごとにパル スを分類して計数する. そのため, 放電であるか, 電解による気泡発生を主とするパルスであるかを 区別していない.

各給電方式の加工時間 $20[\mathrm{~min}]$ 後の $5[\mathrm{~s}]$ 間の電 流パルス数の測定結果を Fig. 6 に示す. 単電極給 電では電流パルス数は約 3700 であった. 分散給 電では各電極での電流パルス数は 890 から 950 で 均一であった，並列給電では，図示した例では電 極 6 だけの電流パルス数が他の電極より特に多か ったが，電極 1 でも電極 2 および 3 より多く発生 した．並列給電では同時にすべての電極で電気分 解が起こる. そして放電は加工物に対してだけで なく, 電解液に対しても起こる. 電極 1 と 6 は並 びの両端であるため, 電解液に対しての放電が頻 繁に起こり，電流パルス数が増加したと考えられ る. 同じ端に位置する電極 1 と電極 6 で差が出た のは，電極保持具の下面が完全に左右対称でない ために泡の蓄積のされやすさなどに差が生じ，放 電の起こりや寸さに差が出たためと考えられる.

分散給電では各電極の電流パルス数の変化が加 工時間に対して少なかったのに対し，並列給電で は電極 1 と 6 の電流パルス数が変化した. このこ とから, 並列給電方式は分散給電方式より周辺の

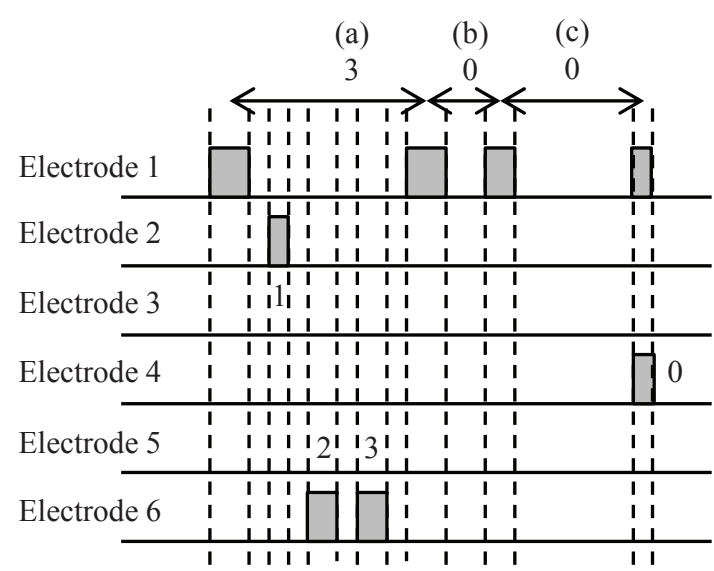

Fig. 7 Definition of number of current pulses at other electrodes

泡などによる影響を受けやすいと考えられる.

\section{3 他電極パルス数}

測定した電流パルスにより, 各電極における電 流パルスの頻度を計算した. 文献 8)で定義した他 電極放電数にならい，ある電極で電流パルスが発 生してから次に電流パルスが発生するまでにほか の電極で発生した電流パルス数を他電極パルス数 と定義する. Fig. 7 を用いて電極 1 に対する他電 極パルス数の数え方を説明する. 同図(a)では電極 1 で電流パルスが発生した後, 電極 2 で 1 回, 電 極 6 で 2 回電流パルスが発生し, 再び電極 1 で発 生している. この場合には他電極パルス数は 3 で ある. 同図(b)では電極 1 で電流パルスが 2 回連続 で発生するうちにほかの電極では発生していない. したがって他電極パルス数は 0 である. 同図(c)で も同図(b) と同様に電極 1 で電流パルスが 2 回連続 で発生している.ただし，2 回目の電流パルスと 同時に電極 4 でも電流パルスが発生しているが, 同時に発生する場合には数えないことにする。し たがって，この場合も他電極パルス数は 0 である とする.このような状態は, 並列給電で数 $[\mathrm{ms}$ 程 度の電流が流れる場合に生じる. 他電極パルス数 が 0 の状態は，同一電極で連続して電流パルスが 発生したことを表している.

Fig. 8 に他電極パルス数の計数結果を示す. 他 の電極で発生した電流パルス数を横軸に, 電極の 番号を奥行の軸に取った. 10 以上は非常に少なか ったため省略した。同図(a)に示した分散給電では, 


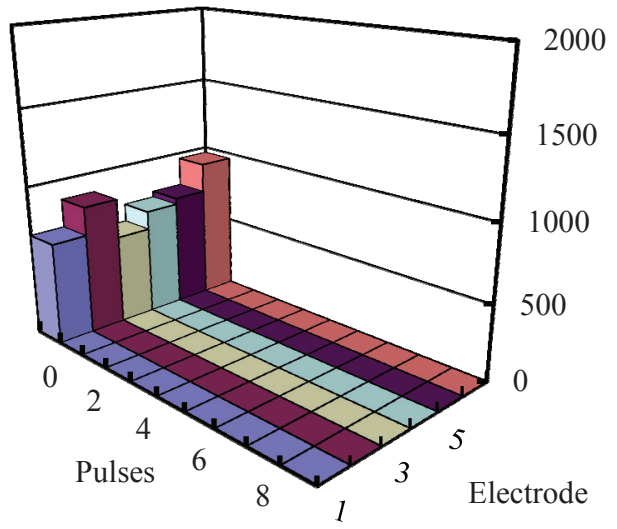

(a) Divided power

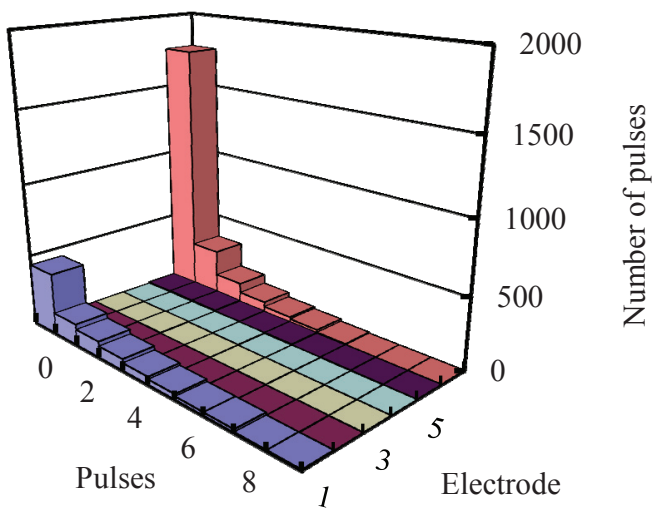

(b) Equi-potential power

Fig. 8 Number of current pulses at other electrodes

電圧が印加される電極が特定されるため, その電 極でしか放電しない，したがって，どの電極でも 他電極パルス数は 0 のみとなった。頻度はほぼ一 定であり，Fig. 6 で示した各電極におけるパルス 数がほぼ一定であることと一致する. 同図(b)に示 した並列給電では, 電極 1 と 6 で 0 の頻度が高か った. しかし他電極パルス数が 1 以上の状態も発 生しており, 1 回の電圧印加時間である $80[\mathrm{~ms}]$ の間でも分散していた.

前報 9)の結果では，加工時間が $20 \sim 40[\mathrm{~min}]$ の 範囲では分散給電の方が並列給電より平均の加工 量が大きかった。また，加工量のばらつきは並列 給電では非常に大きく, 電極 6 では加工量が非常 に大きかった，それに対して，分散給電では加工 量のばらつきが小さかった. Fig. 6 の結果と合わ せると, 電流パルス数が多く, 他電極パルス数 0
の頻度が高いほど加工が進行したと言える.また， 分散給電で加工量のばらつきが小さかったことは, 電流パルス数のばらつきが小さいことと一致した.

\section{4 電流のパルス幅とピーク值}

測定した電流パルスを，パルス幅とピーク值に よりさらに細かく分類した. ピーク值は電流パル スとして検出された範囲の最大值, パルス幅は電 流值がピーク值と定常的に流れている電流 0.3[A] の中間值以上となる時間とした。パルス幅は $20[\mu \mathrm{s}]$ ごと, ピーク值は $0.25[\mathrm{~A}]$ ごとの階級として, パルスを計数した.

分散給電の電極 2 における加工開始後 30 [min] 後から $5[\mathrm{~s}]$ 間のパルス分布を Fig. 9 に示す. 電流 パルス検出のための立ち上がり時のしきい值を 0.5[A]としたため, 0.5[A]未満の階級のパルスは ない. いずれの給電方式でも, 時間経過による分 布の変化はなかった. 同図(a)の単電極では, 他の 給電方式の結果と比べて, パルス幅とピーク值は 広い範囲で分布した。 その中でも $0.5[\mathrm{~A}]$ 以上 1.0[A]未満で $40[\mu \mathrm{s}]$ 未満の範囲のパルス数が多か った. 同図(b)の分散給電では, 0.5[A]以上 $0.75[\mathrm{~A}]$ 未満で $20[\mu \mathrm{s}]$ 未満のパルス数が最も多かった. 全 パルス数が単電極よりも少ないため, その周辺の 範囲のパルス数が少なかったが，比率は単電極と 同程度であった。1[A]以上のパルスは 100〜

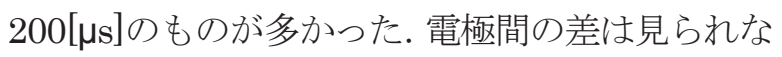
かった，同図(c)の並列給電では，電流值とパルス 幅の範囲は同様であったが, 絶対数が少ないため, 分布の傾向が見られなかった．並列給電の電極 6 の分布を Fig. 10 に示寸. 単電極や分散給電方式 と似た分布となった。この傾向は電極 1 でも同様 であった．内側の電極に面していない部分では泡 の流れがほかの給電方式と同様に放射状に広がる ため 9), 電流パルスの分布も同様であったと考え られる。

泡の発生過程と放電位置の模式図を Fig. 11 に 示寸. 同図(a)は泡の発生の初期過程で, 電圧印加 と同時に工具電極の表面から電解により複数の泡 が発生し始める. 時間が経つと同図(b)のように工 具電極表面全体が泡で覆われる.さらに時間が経 つと同図(c)のように泡が合体し，膜が形成されて 工具電極が電解液から絶縁される 12). 電解液の方 


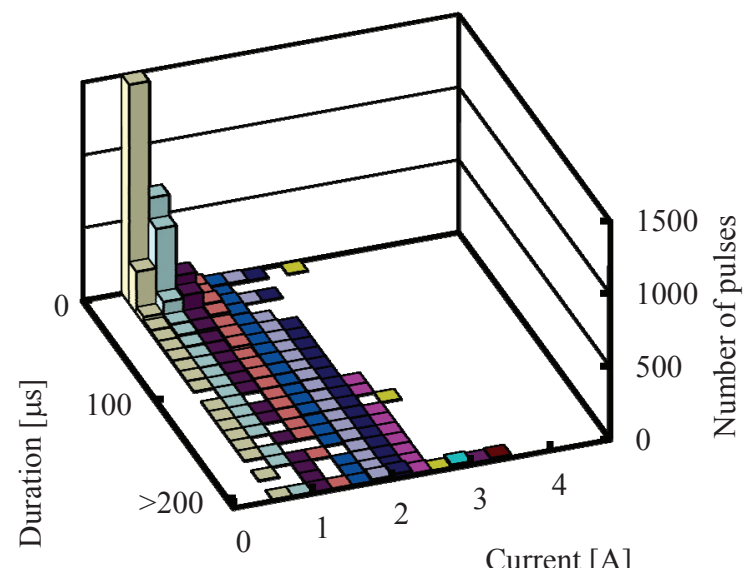

(a) Single electrode

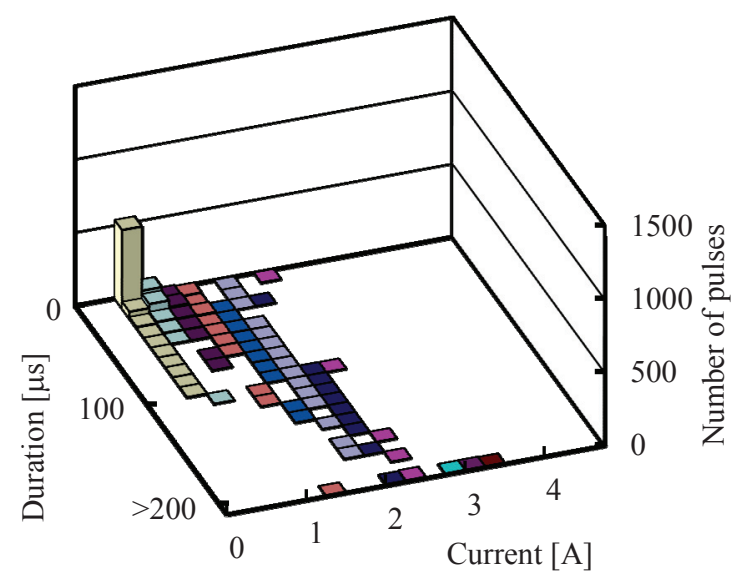

(b) Divided power

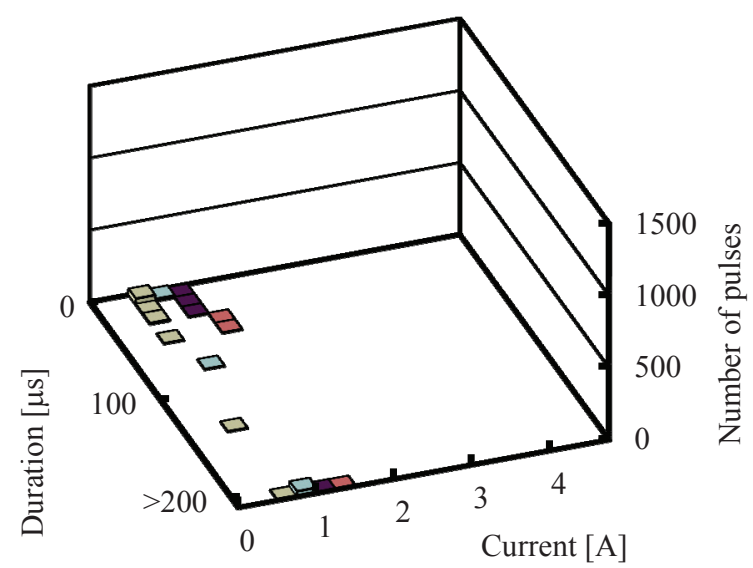

(c) Equi-potential power

Fig. 9 Distributions of peak and duration (Electrode 2)

が純水や油より表面張力が大きいため，合体しや すい，電流が $0[\mathrm{~A}]$ になるときがある場合には ${ }^{12)}$,

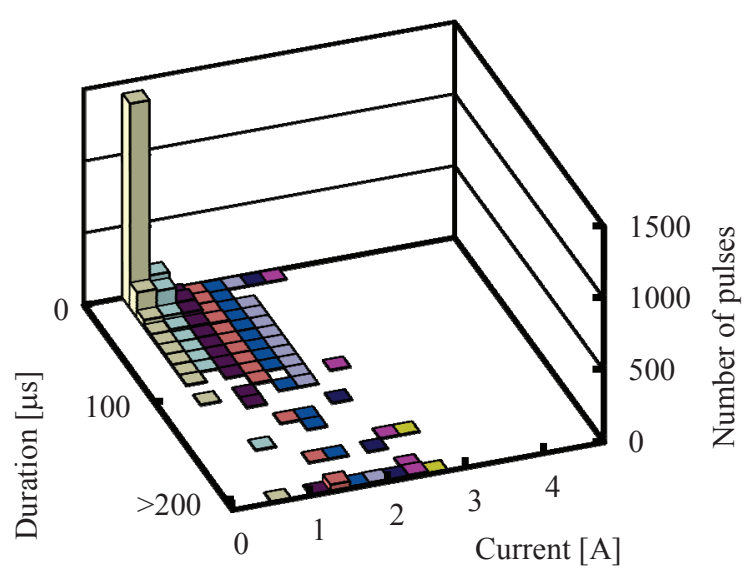

Fig. 10 Distributions of peak and duration at electrode 6 by equi-potential power

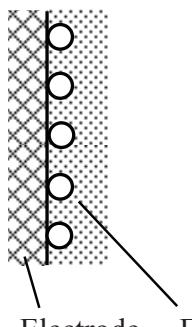

Electrode

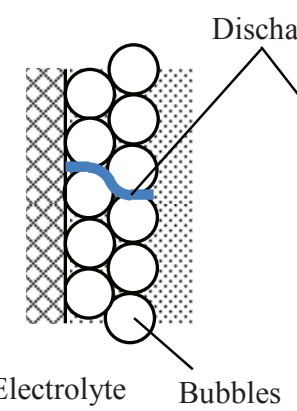

$\begin{array}{llll}\text { (a) Nucleation } & \text { (b) Bubble layer } & \text { (c) Gas film }\end{array}$

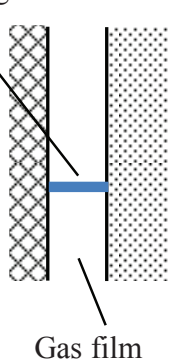

$\begin{array}{llll}\text { (a) Nucleation } & \text { (b) Bubble layer } & \text { (c) Gas film }\end{array}$

Fig. 11 Progress of bubble layer and gas film formation, and discharge path

この状態でも放電していると考えられる. 一方, Figs. 3 から 5 に示した電流の観察結果では, いず れの給電方式でも常に $0.3[\mathrm{~A}]$ 程度の電流が流れて いた. したがって, Fig. 11(c)のように電極が完全 に電解液から絶縁され, 膜内で放電が発生すると は考えにくい, 一方, 同図(b)の段階で泡の境界を 電流が流れるというモデルが提案されている3).

これに基づいた電流経路を Fig. 12 に示寸. ピー ク值とパルス幅は以下のように考えることができ る. 重力により電極が送られるため, 電極底面は 工作物と接触している. したがって, その近傍で は間隙が小さいので泡の量が少ない, さらに, 電 解液中の泡がない領域までの泡の境界が長い。 そ のためピーク值が小さくなる. そして, 電流が流 れることで境界が消滅すると電流が流れなくなる ためパルス幅が短くなる，また，電極側面は泡が 


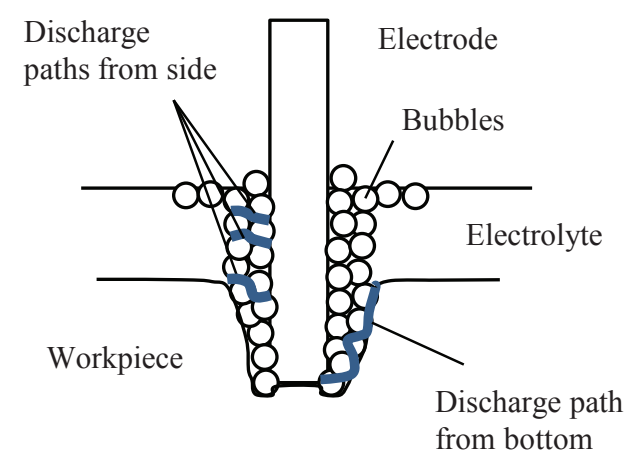

Fig. 12 Discharge paths during machining

覆う面積が広く, 工具電極から電解液までの距離 が短いため抵抗が小さくなる，その結果，ピーク 值が大きくなるとともに，一部の泡の境界が消滅 しても他の境界を流れることができる.

\section{5 考察}

加工形状と測定された電流パルスの関係につい て考える.

泡の発生と消滅の現象は, 程度の違いはあるが, すべての給電方式で共通である，工具電極に電圧 を印加すると電気分解が起こり, 泡が電極を覆う. さらに，電気分解が起こると泡の数が増え，泡は 層を成すように電極の周りに集まる，泡はいくつ か集まると，ひとつの大きな泡になる．それと同 時に, 泡は大きくなると割れて消滅する.

単電極給電では, 目視では常に泡が発生し続け るように見えるが，泡の層の厚さは以下のように 変化すると考えられる. 電圧を印加すると電気分 解によって発生した泡が工具電極を覆う.しかし, 最初はその層が薄いため抵抗值は小さく, 泡の境 界付近をピーク值の高い電流が流れると考えられ る. 電圧印加をオフにしても $20[\mathrm{~ms}]$ 間では完全に 泡が消滅しないため，泡は常に電極の周りに存在 する. この状態で再び電圧を印加すると, 電極周 辺に何もない状態から電気分解を行ったときより も泡の量は多くなり, 層が厚くなる. その結果, 抵抗值が増加し電流は流れにくくなり，流れたと してもピーク值は低くなると考えられる. 電流が 流れにくくなると, 電気分解により発生する泡の 量が減少する.これが繰り返されるため, Fig. 9(a) に示寸ようにさまざまなパルス幅やピーク值を持 つ電流パルスが流れたと考えられる，泡が消滅す
るときには新しい加工液が流入するので, 化学反 忘に必要な $\mathrm{Na}^{+}$イオンが供給される. そこに放電 が発生すると, その熱により化学反応が促進され てケイ酸ナトリウムの生成量が増加寸る, これが 電解液に溶解寸ることで加工が進んだと考えられ る.

分散給電では, 目視では各電極における泡の発 生量が単電極給電よりも少なかった. これは休止 時間が他の給電方式より長く, 泡はその間に消滅 したことが原因であると考えられる。この場合に は, 泡の層が厚くなることは少なく, 抵抗值が低 いので, Fig 9(b)に示すようにピーク值の高い電 流が流れたと考えられる.すべての電極で，周り に泡が少ない状態から電気分解が開始され，隣り 合う電極の影響を受けにくい. 各電極じうしで比 較した場合の加工深さや長径, 短径など加工穴の 形状のばらつきが小さかったのは 9)，これが原因 であると考えられる。

並列給電方式では，目視では泡の発生量が最も 多かった. 6 本の電極が並列に接続されているた め, 印加電圧の休止時間は単電極給電と同じであ る. かつ, ほかの方式よりも電極の表面積合計が 大きい。したがって, 電極と電解液を隔てている 泡の数が多く, 抵抗值は最も低い. 大量に発生し た泡は合体し，大きくなると割れて消滅する。 そ の結果, すべての電極を泡で覆うために, 電解作 用を起こすパルス幅の長い電流が頻繁に流れたが, 放電と考えられる短いパルス幅の電流が発生しに くかったと考えられる。電極 2 から電極 5 までは 泡が滞留するが, 電流パルスは少なく, ピーク值 が低かった。しかし, 電極の並びの両端であるた め電極 1 と電極 6 の加工穴では他の加工穴に比べ て, 新しい加工液が流入しや寸く, 化学反応が起 こりやすい. そのため, 電極 1 と電極 6 で加工が 進んだ9) と考えられる.

以上のことより, 電解放電加工を用いて絶縁体 の 3 次元微細形状を創成するときに加工性能をよ り改善するためには, 加工穴内部でのみ放電が発 生するように分散給電により泡の発生位置を制御 することや, だれや突起, 加工穴の断面形状が膨 らむことのないように泡の発生量を制御する必要 があると考えられる。 


\section{4. 結 論}

本論文では電解放電加工において複数の電極を 用いて放電を分散させて，電流波形を測定した. 結果をまとめると以下のようになる.

（1）単電極給電方式と分散給電方式とでは，電圧 を印加した電極の周りに泡が十分に発生し てから放電が発生するため，電流パルスの分 布が類似していた。

（2）並列給電方式では，中央の電極周辺で泡が滞 り抵抗が高くなるため, 両端の電極で放電が 連続して発生した。

（3）加工に寄与する放電電流と考えられるパル スは，パルス幅 40[ $\mu \mathrm{s}]$ 未満でピーク值 $1[\mathrm{~A}]$ 以下の範囲で多く発生していた。

\section{謝 辞}

研究の遂行にあたり豊田工業大学・松原弘明氏 にご協力いただきました.

本研究の一部は科学研究費補助金基盤研究(C) （18560118），基盤研究(C)(21560134)および文部 科学省私立大学戦略的研究基盤形成事業「難環境 作業スマート機械システム技術研究センター」補 助金によるものです. 記して感謝いたします.

\section{参考文献}

1) H. Kurafuji, K. Suda: Electrical Discharge Drilling of Glass I, Ann. CIRP, Vol. 16, (1968), pp. 415-419.

2) R. Wüthrich, V. Fascio: Machining of Non-conducting Materials Using Electrochemical Discharge Phenomenon An Overview, Int. J. Mach. Tool. Manuf., Vol. 45, No. 9, (2005), pp. 1095-1108.

3) I. Basak, A. Ghosh: Mechanism of spark generation during electrochemical discharge machining: a theoretical model and experimental verification, J. Mater. Process. Technol., Vol. 62, No. 1-3, (1996), pp. 46-53.

4) A. Paul: Chemistry of Glasses, Chapman and Hall, London, UK, (1982), pp. 109-111.

5) K. Furutani, H. Maeda: Machining glass rod with lathe type electro-chemical discharge machine, J. Micromech. Microeng., Vol. 18, No. 6, 065006, (2008), pp. 1-8.

6) K. Furutani, K. Arai: Measurement of Machining Force in Lathe Type Electro-chemical Discharge Machine, Proc. 11th Int. Conf. euspen, Como, Italy, (2011), pp. 220-223.

7) K. Furutani, T. Enami, N. Mohri: Three-dimensional Shaping by Dot-matrix Electrical Discharge Machining, Precis. Eng., Vol. 21, No. 2/3, (1997), pp. 65-71.

8) N. Mohri, K. Furutani, K. Shirai, T. Enami: Forced Discharge Dispersion by Dot-Matrix Method, Ann. CIRP, Vol. 46, No. 1, (1997), pp. 139-142.

9）古谷克司, 新谷啓行, 村瀬靖男, 荒川修一: 強 制放電分散型電解放電加工の加工特性, 電気加 工学会誌，47, 116 (2013) , pp. 169-176.

10) W. Y. Peng, Y. S. Liao: Study of electrochemical discharge machining technology for slicing non-conductive brittle materials, J. Mater. Process. Technol., Vol. 149, No. 1-3, (2004), pp. 363-369.

11) D. J. Kim, Y. Ahn, S. H. Lee, Y. K. Kim: Voltage pulse frequency and duty ratio effects in an electrochemical discharge microdrilling process of Pyrex glass, Int. J. Mach. Tool. Manuf., Vol. 46, No. 10, (2006), pp. 1064-1067.

12) A. Kulkarni, R. Sharan, G.K. Lal: An experimental study of discharge mechanism in electrochemical discharge machining, Int. J. Mach. Tool. Manuf., Vol. 42, No. 10, (2002), pp. 1121-1127.

(2013年8月 21日受付) 